\title{
Pengaruh Teknologi Informasi dan Sistem Informasi Perpajakan Terhadap Kinerja Manajerial Keuangan
}

\section{Myra Andriana}

Sekolah Tinggi Elektronika dan Komputer

my_andriana@yahoo.com

\section{Tantiek Sumarlin}

Sekolah Tinggi Elektronika dan Komputer tantiksumarlin@yahoo.co.id

\section{Roymon Panjaitan}

Sekolah Tinggi Elektronika dan Komputer roymon_panjaitan@yahoo.com

\begin{abstract}
The company's financial managerial performance is heavily based on several factors in the decision making process. The factor analysis indicated on several factors independent variables are information technology and information systems of taxation. Both variables are the gauge of their influence on managerial performance in some manufacturing industries. This study was aimed to prove empirically the influence of information technology and information system on financial manager performance of manufacturing companies in Semarang district. The research data collection process through interview and questionnaire on with random data of 95 respondents with purposive sampling method. Analysis of data used with validity and reliability tests, testing using $T$ test, $F$ test and coefficient of determination. The results of this study showed there was a positive influence on information technology and information systems simultaneously based on the value of Adjusted $R$ Square (R2) Information technology variables of $57 \%$ and the system variables of taxation information of 43\% against performance Financial management in the manufacturing company.
\end{abstract}

Keyword : Information Technology, Tax Information Systems, Financial Managerial Performance

\section{PENDAHULUAN}

Di era globalisasi sekarang ini, suatu negara yang berkembang diukur dari tingkat pertumbuhan ekonomi warga negaranya. Pertumbuhan ekonomi negara yang bergerak maju sangat ditunjang oleh beberapa faktor - faktor yaitu di antaranya pengaruh media sistem dan teknologi informasi. Industri manufaktur pada khususnya berusaha menciptakan segala sistem teknologi informasi yang dibuat secara efektif dan efisien. 
Sumber daya dan pemikiran manusia yang sudah ada lama kelamaan akan tergantikan dengan kehadiran teknologi informasi kecerdasan buatan (artificial intelligence). Proses transformasi ini akan membantu para investor, shareholder, dan stakeholders untuk menghemat segala sumber daya yang diperlukan dengan efisien. Salah satu contoh peran manusia yang sudah digantikan oleh sistem teknologi informasi secara khusus di bidang financial technology (fintech) yaitu transformasi sistem pembayaran berbasis kas menjadi smartcard, sistem pembayaran tunai menjadi e-cash seperti OVO, Dana, Go - Pay, dan lain - lain. Hal ini akan berdampak kepada industri - industri manufaktur yang harus jeli dalam menerima kehadiran sistem teknologi seperti ini, karena bisa menjadi suatu peluang atau sebaliknya akan menjadi ancaman jika dalam proses produksi industri tidak mampu mengembangkan teknologi informasi dan sistem informasi yang berdampak terhadap produktivitas penjualan perusahaan.

Oleh karena adanya perubahan tersebut, peneliti merumuskan masalah secara khusus yang terjadi dalam fenomena masyarakat di bidang industri manufaktur yaitu pemanfaatan sumber daya dan pemanfaatan informasi perpajakan sebagai kebaruan dalam penelitian ini. Pemanfaatan sumber daya tersebut diperoleh dari ilmu pengetahuan yang mengadopsi teknologi dalam pemrosesannya sehingga secara otomatis akan meningkatkan produktivitas perusahaan manufaktur. Indikator suatu perusahaan akan produktif berasal dari manusia (human resourses) yang berfikir secara efektif dengan menggunakan media teknologi sebagai basis model pengerjaannya. Pengimplementasian basis teknologi dalam pengerjaannya, akan berdampak positif dalam menyelesaikan pekerjaan dengan akurat. Perkembangan teknologi yang agresif membuat para pelaku industri (user) dalam harus semakin peka dan mengupdate segala informasi yg setiap saat akan mengalami perubahan.

Sistem informasi perpajakan merupakan alat yang dimasukan ke dalam bidang teknologi informasi (TI), yang dirancang untuk membantu pengelolaan dan pengendalian terkait bidang keuangan dan perpajakan. Disiplin ilmu perpajakan berisi informasi yang dibutuhkan untuk mengikuti segala ketentuan undang - undang perpajakan. Menurut Anonim dalam Herda (2018) perusahaan yang menguasai sistem informasi memiliki keunggulan kompetitif dalam lingkungan makro bisnis.

Perubahan dan penggunanaan teknologi akan merubah sistem dari manual, semi manual menjadi robotic di dalam proses organisasi. Kemampuan dalam menggunakan teknologi dan sistem informasi menjadi salah satu indikator terjadinya kemajuan teknologi dalam industri di segala bidang, sebagai media pemasaran dan bisnis yang berkelanjutan. Menurut Lucas \& Spitler dalam Ayu dan Sri (2016), supaya penggunaan sistem dan teknologi informasi dapat berguna bagi user nya dan mambantu pekerjaan dengan terstruktur, oleh karena itu setiap pelaku usaha harus mampu meningkatkan kompetensinya.

Tujuan penelitian ini, kami ingin memperluas varibel sistem informasi perpajakan sebagai salah satu kebauran yang diperlukan dalam hubungannya dengan perencanaan pajak dan tentunya akan mempengaruhi kinerja manajerial keuangan dalam pengambilan keputusan. Adanya keterkaitan teknologi informasi yang berdampak kepada produktifitas manajerial telah diteliti sebelumnya, diantaranya Frestilia (2013), Ardhi (2015), dan Adnan (2016) yang berpendapat penggunaan aspek teknologi memberikan implikasi 
positif dan diketahui adanya perubahan drastis terhadap kinerja manajerial. Namun di setiap industri yang masih bersifat konservatif masih belum mampu menerapkan teknologi dalam proses produksinya, dikarenakan biaya yang mahal untuk pembelian mesin atau teknologi dalam proses produksinya. Dari latar belakang dan adanya gap tersebut, penelitian ini berkontribusi untuk meberikan masukan dalam analisa kualitatif mengenai keterkaitan antara sumber daya teknologi yang digunakan dan sistem informasi perpajakan terhadap produktivitas kerja level manajer pada industri manufaktur di Kabupaten Semarang.

\section{LANDASAN TEORI}

1. Teknologi Informasi

Menurut Williams \& Sawyer dalam Joko dan Gun (2018) teknologi informasi merupakan sebuah bentuk umum yang menggambarkan setiap teknologi yang membantu menghasilkan, memanipulasi, menyimpan, mengkomunikasikan, dan atau menyampaikan informasi. Teknologi informasi (TI) secara umum didefinisikan sebagai perpaduan antara teknologi komputer dengan teknologi lainnya. Definisi teknologi informasi secara lengkap dinyatakan sebagai teknologi komputer yang digunakan untuk memproses dan menyimpan informasi serta teknologi komunikasi yang digunakan untuk mengirimkan informasi (Herda, 2018).

Hansen dan Mowen (2009:4) menyatakan bahwa teknologi informasi berbasis komputer merupakan salah satu teknologi informasi yang banyak berpengaruh terhadap sistem informasi organisasi karena dengan sistem informasi berbasis komputer dapat disajikan tepat waktu dan akurat. Alasan utama penggunaan teknologi informasi dalam bisnis menuut Haag dan Cummings dalam Satria (2015) yaitu karena teknologi informasi mendukung tugas pemrosesan informasi yang meliputi lima kategori yaitu menangkap, menyampaikan, menciptakan, menyimpan dan mengkomunikasikan informasi.

\section{Sistem Informasi Perpajakan}

Sistem informasi adalah suatu sistem didalam organisasi yang mempertemukan kebutuhan pengelolaan transaksi harian, mendukung operasi, bersifat manajerial, dan kegiatan strategi dari suatu organisasi dan menyediakan pihak luar tertentu dengan laporan-laporan yang dibutuhkan (Japerson, 2015). Martin et al dalam Ayu dan Sri (2016) mengungkapkan bahwa sistem informasi sistem membantu pimpinan dan karyawan untuk menganalisis permasalahan, memvisualisasikan subyek yang komplek dan menciptakan produk baru. Sistem informasi perpajakan merupakan suatu sistem yang dirancang untuk membantu pengelolaan dan pengendalian terkait bidang keuangan dan perpajakan. Sistem informasi perpajakan menyediakan informasi yang dibutuhkan untuk memenuhi tujuan-tujuan manajemen dalam bidang perpajakan.

\section{Kinerja Manajerial Keuangan}

Kinerja manajerial menunjukan kemampuan manajemen dalam menjalankan fungsi manajemen yang merupakan aktivitas bisnis, yang tentu selalu berkenaan dengan pengambilan keputusan (Anik dan Rico, 2018). Kinerja manajerial merupakan hasil dari proses aktivitas manajerial yang mulai dari proses perencanaan, pelaksanaan, pemantauan usaha, laporan pertanggungjawaban, pembinaan, dan pengawasan Menurut Mahoney et.al kinerja manajerial merupakan seberapa jauh manajer melaksanakan fungsi-fungsi 
manajemen yang diukur menggunakan indikator perencanaan, investigasi, koordinasi, evaluasi, supervisi, staffing, negosiasi, dan representasi.

\section{Kerangka Konseptual}

\subsection{Pengaruh Teknologi Informasi terhadap Kinerja Manajerial}

Pengimplementasian dari sumber daya yang dimiliki dalam suatu perusahaan dapat dilihat dari kemudahan pemakai dalam mengenali data, penggunaan, dan menginterpretasi transaksi. Sumber transaksi keuangan yang diperoleh oleh pihak manajerial harus bisa terkoneksi antar divisi bagian kerja, hal ini dituntut untuk memberikan dan menerima informasi dengan penghematan waktu atau cepat, akurat dan efisiensi sumber daya yang diperlukan sebagai fungsi kendali internal (internal control). Pemanfaatan ini akan terintegrasi dengan data (Entreprise Resources Planning) dalam internal perusahaan, sedangkan kegunaan informasi media bagi pihak luar akan terhubung dengan sistem (Costumer Relationship Management) yang digunakan sebagai penghubung antara industri dengan supplier atau media penyedia bahan baku. Sehingga segala bentuk kebutuhan data dan pelayanan dalam bentuk koordinasi, pelaporan, dan prosedur administratif untuk mendukung kinerja manajerial dapat dilakukan secara cepat, tepat, dan akurat.

Penggunaan teknologi dalam sistem informasi hendaknya mempertimbangkan pemakai. Tidak jarang ditemukan bahwa teknologi informasi yang diterapkan tidak tepat atau tidak dimanfaatkan secara maksimal oleh pemakainya, sehingga tidak berkontribusi dalam meningkatkan kompetensi manajerial. Di dalam industri manufaktur, seorang manajer kadang kala harus mengambil keputusan taktis dan dinamis dalam menghadapi persaingan tingkat global. Informasi yang terkini dan terstruktur akan membantu dalam proses (decision making) yang lebih akurat. Penggunanan teknologi ini sebagai salah satu variabel yang akan memberikan kontribusi dalam pencapaian target dan kinerja karyawan di perusahaan manufaktur. Berdasarkan hasil riset dan analisa data yang sudah diolah lebih dahulu maka dugaan pertama dalam pengamatan ini yaitu :

$\mathrm{H}_{1}$ : Pendayagunaan teknologi informasi memberikan pengaruh terhadap kinerja manajerial pada perusahaan manufaktur di Kabupaten Semarang

\subsection{Pengaruh Sistem Informasi Perpajakan terhadap Kinerja Manajerial}

Sistem informasi perpajakan sebagai seperangkat informasi yang dibuat oleh manusisa dari ketentuan - ketentuan perpajakan yang sudah terbentuk, kemudian menjadi aliran informasi dalam proses produksi yang bertujuan membantu perencanaan manajemen keuangan untuk mendapatkan angka yang akurat dalam perhitungan perpajakan dalam perhitungan perencanaan pajak (tax planning). Perencanaan pajak perlu dilakukan oleh manajerial untuk merencanakan besarnya biaya pajak yang akan dipotong dari seluruh pendapatan dikurangi dengan biaya - biaya sebelum pajak dengan biaya setelah pajak sehingga diketahui besarnya laba perusahaan. Pemanfaatan sistem informasi perpajakan memberikan dampak yang signifikan. Berdasarkan sumber data penelitian terdahulu yang menyatakan bahwa sistem informasi secara parsial mendeteksi adanya korelasi positif terhadap kinerja di bagian top level manajemen. Berdasarkan hasil penelitian yang sudah ada lebih dulu, maka hipotesis kedua dalam penelitian ini adalah: $\mathrm{H}_{2}$ : Penggunaan sistem informasi perpajakan berkontribusi terhadap kinerja manajerial pada perusahaan manufaktur di Kabupaten Semarang 


\subsection{Pengaruh Teknologi Informasi dan Sistem Informasi Perpajakan terhadap Kinerja Manajerial}

Pemanfaatan teknologi informasi sebagai media untuk menghasilkan, memanipulasi, menyimpan, mengkomunikasikan, dan menyampaikan informasi, serta sistem informasi perpajakan sebagai suatu perangkat yang terdiri dari manusia dan sumber modal yang berkontribusi dalam proses penyusunan laporan keuangan sehingga didapat informasi yang berkaitan dengan perpajakan secara bersamaan dapat mempengaruhi pencapaian kunci indikator kinerja. Hal ini sesuai dengan hasil penelitian terdahulu yang menyatakan bahwa penggunaan sumber informasi dan sistemnya secara bersama terindikasi signifikan kepada setiap pengusaha manufaktur khususnya. Dengan mengacu pada teori dan penelitian terdahulu, maka hipotesis ketiga dalam penelitian ini adalah:

$\mathrm{H}_{3}$ : Pendayagunaan sumber teknologi dan informasi perpajakan secara bersamaan akan berpengaruh terhadap kompetensi skill manajerial pada perusahaan manufaktur di Semarang

\section{METODOLOGI PENELITIAN}

Populasi dan sampel dalam penelitian ini adalah karyawan perusahaan industri manufaktur yang berada di kabupaten Semarang dan metode pengambilan sampel menggunakan purposive sampling. Teknik pengumpulan data yang digunakan dalam penelitian ini adalah dengan menggunakan media kuesioner dan media internet dan diinput ke dalam tabulasi data kemudian diolah menggunakan software SPSS 19. Metode kuisioner dengan pernyataan skala likert. Pada kuesionner yang diberikan kepada responden terdapat pilihan jawaban berupa skala 1 sampai dengan 5 yang mempunyai gradasi dari sangat tidak setuju hingga sangat setuju.

Model penelitian ini menggunakan modal regresi linear berganda yang menyatakan bahwa diduga variable independen yaitu, Teknologi Informasi dan Sistem Informasi Perpajakan memberikan dampak terhadap variabel bergantung yaitu Kinerja Manajerial Keuangan. Adapun model penelitian dapat dirumuskan sebagai berikut :

$\mathbf{Y}=\mathbf{a}+\boldsymbol{\beta 1}$ Teknologi Informasi + $\beta 2$ Sistem Informasi Perpajakan + ui

$\begin{array}{llll}\text { Keterangan : } & \mathrm{Y} & = & \text { Kinerja Manajerial Keuangan } \\ \mathrm{a} & = & \text { Konstanta } \\ \mathrm{X}_{1} & = & \text { Teknogi Informasi } \\ \mathrm{X}_{2} & = & \text { Sistem Informasi Perpajakan } \\ \mathrm{b}_{1}, \mathrm{~b}_{2}= & \text { Koefisien Variabel } \mathrm{X}_{1}, \mathrm{X}_{2}, \\ \mathrm{ui} & = & \text { Faktor gangguan (Gujarati, 1995:130) }\end{array}$

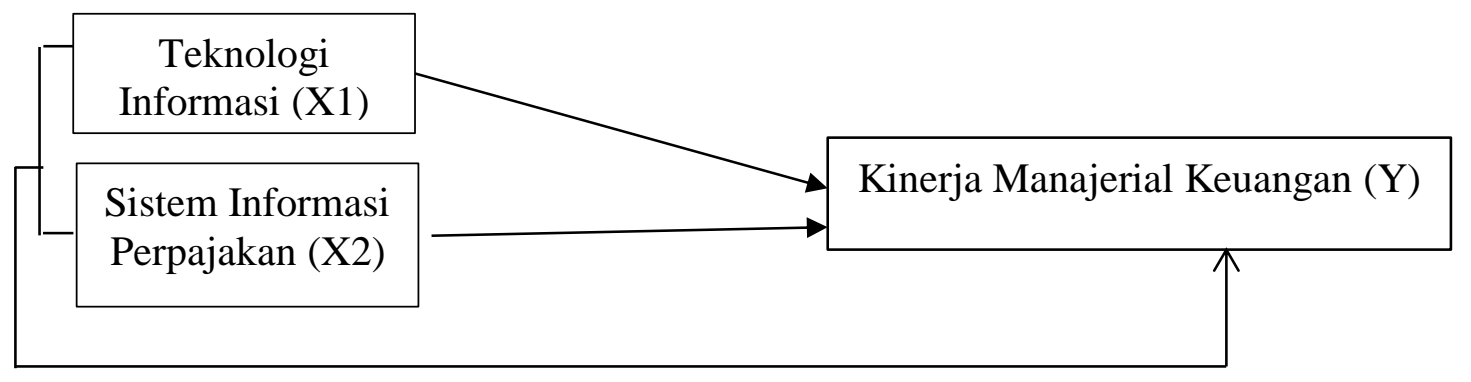

Gambar 1. Model Penelitian 
Teknis analisis data dalam menggunakan kedua independen variabel terhadap dependen variabel yaitu :

\section{Uji validitas dan reliabilitas}

Penilaian terhadap uji ini berguna untuk memberikan penilaian terhaap suatu obyek yang dilakukan dengan menggunakan data empiris dan argumentasi nalar yang memberikan kesimpulan bahwa data tersebut tepat. Validitas diperoleh dari karakteristik terhadap suatu obyek tes pada suatu instrumen pengukuran yang dikumpulkan dari kolektivitas data empiris dan argumentasi logis pada suatu tujuan kesimpulan tertentu. Validitas merupakan hasil turunan dari validasi yang dapat dikelompokkan menjadi validitas internal dan eksternal. Sedangkan uji reliabilitas adalah tingkat pengukuran yang dapat dipercaya. Nilai reliabilitas yang tinggi jika memberikan hasil yang tetap walaupun diberikan pada waktu dan responden yang sama pula. Hasil tes yang tetap atau seandainya berubah maka perubahan itu tidak signifikan dan disebut reliabel. Indikator ini akan menyangkut masalah ketepatan alat ukur.

\section{Uji Kelayakan Model}

Uji kelayakan model digunakan untuk mengukur ketetapatan fungs regresi dari sampel yang dipilih dalam menaksir nilai aktual yang disebut dengan koefisien determinasi. Berdasarkan hasil dari kumpulan yang kemudian diolah didapatkan berada dalam daerah yang terindikasi berpotensi maka $\mathrm{H}_{\mathrm{o}}$ ditolak, sebaliknya apabila dari hasil uji yang korelasinya tidak berkontribusi maka $\mathrm{H}_{\mathrm{o}}$ diterima.

\section{Uji Regresi}

Analisis penurunan adalah suatu bentuk analisa yang diperoleh dari data atau transaksi aktual dengan data perkiraan yang masih belum akurat atau dalam bentuk perkiraan, yang korelasinya belum bisa dipastikan dengan tepat karena masih ada sebagian penyimpanagan yang terjadi. Maka dari itu uji regresi adalah teknik perkiraan untuk pengukuran suatu variabel yang berdiri sendiri dengan variabel yang bisa berdampak terhadap hasil ujinya.

\section{HASIL PENELITIAN DAN PEMBAHASAN}

\section{Hasil Analisis Data Validitas dan Reliabilitas}

Dari kuesioner yang didistribusikan dan pengolahan tabulasi data penelitian ini memperoleh 95 responden yang merupakan manajer pada perusahaan manufaktur di wilayah Kabupaten Semarang. 
Tabel Hasil Pengujian Validitas

\begin{tabular}{|c|c|c|c|c|}
\hline Variabel & Indikator & $\begin{array}{c}\text { rhitung } \\
\text { (Corrected } \\
\text { Item-Total } \\
\text { Correlation) }\end{array}$ & $\begin{array}{l}> \\
1 \\
<\end{array}$ & $\begin{array}{c}\text { rTabel } \\
(\alpha=0,05)\end{array}$ \\
\hline Teknologi & $\mathrm{x} 11$ & 0.355 & $>$ & 0,202 \\
\hline Informasi & $\mathrm{x} 12$ & 0.366 & $>$ & 0,202 \\
\hline \multirow[t]{4}{*}{ (X1) } & $\mathrm{x} 13$ & 0.350 & $>$ & 0,202 \\
\hline & $\mathrm{x} 14$ & 0.498 & $>$ & 0,202 \\
\hline & $\mathrm{x} 15$ & 0.504 & $>$ & 0,202 \\
\hline & $\mathrm{x} 16$ & 0.508 & $>$ & 0,202 \\
\hline Sistem & $\mathrm{x} 21$ & 0.635 & $>$ & 0,202 \\
\hline Informasi & $\mathrm{x} 22$ & 0.511 & $>$ & 0,202 \\
\hline Perpajakan & $\mathrm{x} 23$ & 0.455 & $>$ & 0,202 \\
\hline \multirow[t]{3}{*}{ (X2) } & $\mathrm{x} 24$ & 0.479 & $>$ & 0,202 \\
\hline & $\mathrm{x} 25$ & 0.485 & $>$ & 0,202 \\
\hline & $\mathrm{x} 26$ & 0.502 & $>$ & 0,202 \\
\hline Kinerja & $\mathrm{y} 1$ & 0.565 & $>$ & 0,202 \\
\hline Manajerial & $y^{2}$ & 0.343 & $>$ & 0,202 \\
\hline Keuangan & y3 & 0.431 & $>$ & 0,202 \\
\hline \multirow[t]{3}{*}{$(\mathrm{Y})$} & $\mathrm{y} 4$ & 0.549 & $>$ & 0,202 \\
\hline & y5 & 0.552 & $>$ & 0,202 \\
\hline & y6 & 0.665 & $>$ & 0,202 \\
\hline
\end{tabular}

Sumber : Olah data utama yang diperoleh tahun 2019

Hasil analisa menunjukkan bahwa setiap item pertanyaan dalam kuisioner adalah valid. Setiap item pertanyaan menunjukkan nilai diatas $r$ tabel sebesar 0,202 dengan jumlah responden $(\mathrm{N})$ sebanyak 95. Nilai $r$ hitung $>r$ tabel dengan $N=95, \alpha=0,05$

Tabel Hasil Pengujian Reliabilitas

\begin{tabular}{|l|r|r|c|}
\hline Variabel & $\begin{array}{c}\text { r hitung } \\
\text { (Cronbach's } \\
\text { Alpha })\end{array}$ & $/$ & r standart \\
\hline (X1) & 0,741 & $>$ & 0,60 \\
$(\mathrm{X} 2)$ & 0,811 & $>$ & 0,60 \\
$(\mathrm{Y})$ & 0,624 & $>$ & 0,60 \\
& & $>$ & 0,60 \\
\hline
\end{tabular}

Sumber : Olah data utama yang diperoleh tahun 2019 
Nilai Cronbach's Alpha dari masing-masing variabel, Teknologi Informasi (X1), Sistem Informasi Perpajakan (X2) dan Kinrja Manajerial Keuangan (Y) menunjukkan nilai yang lebih besar dari $r$ standar sebesar 0,60. Jadi kesimpulannya bahwa setiap variabel tersebut reliabel.

\section{Hasil Uji Kelayakan Model}

\begin{tabular}{|c|c|c|c|}
\multicolumn{1}{|c|}{ Tabel Koefisien Determinasi } \\
Model & $\mathrm{R}$ & $\mathrm{R}$ Square & $\begin{array}{c}\text { Adjusted R } \\
\text { Square }\end{array}$ \\
\hline 1 & $.761^{\mathrm{a}}$ & .579 & .570 \\
\hline
\end{tabular}

Sumber : Olah data utama yang diperoleh tahun 2019

Nilai Adjusted R Square $\left(\mathrm{R}^{2}\right)$ sebesar $57 \%$ yang berarti bahwa pengaruh variabel teknologi informasi (X1) dan variabel sistem informasi perpajakan (X2) sebesar $57 \%$, dan sisanya $43 \%$ dipengaruhi oleh faktor lain.

Tabel Uji F
\begin{tabular}{|c|c|c|}
\hline Model & F & Sig. \\
\hline 1 & 63.284 & $.000^{\mathrm{a}}$ \\
\hline
\end{tabular}

Sumber : Olah data utama yang diperoleh tahun 2019

Nilai F hitung sebesar 63.284 dan hasil F tabel sebesar 3.0954. Menunujukkan bahwa nilai $\mathrm{F}$ hitung labih besar dari $\mathrm{F}$ tabel dengan nilai signifikansi sebesar 0.000 yang jauh dari 0.05. Jadi dapat dikatakan bahwa model persamaan regresi tersebut layak untuk digunakan.

Dari uji F, menunjukkan nilai signifikansi sebesar 0,000, jauh lebih kecil dari 0,05. Yang berarti bahwa secara bersama-sama variabel teknologi dan sistem informasi perpajakan berkontribusi secara parsial kepada variabel kompetensi manajerial keuangan sebagai variabel dependennya .

\section{Hasil Uji Hipotesa}

Uji hipotesis 1 (H1) : pengaruh teknologi informasi terhadap kinerja manajerial keuangan sebesar 6.277 dengan nilai $\mathrm{T}$ tabel sebesar 1.986. $\mathrm{T}$ hitung $>\mathrm{T}$ tabel dengan demikian diduga ada pengaruh positif teknologi informasi terhadap kinerja manajerial keuangan pada perusahaan manufaktur.

Uji hipotesis $2(\mathrm{H} 2)$ : pengaruh sistem informasi perpajakan terhadap kinerja manajerial keuangan sebesar 4.835 dengan nilai $\mathrm{T}$ tabel sebesar 1.986. $\mathrm{T}$ hitung $>\mathrm{T}$ tabel dengan demikian diduga ada pengaruh positif pengaruh sistem informasi perpajakan terhadap kinerja manajerial keuangan pada perusahaan manufaktur. 
Tabel koefisiensi regresi

\begin{tabular}{|c|c|c|c|c|}
\hline \multirow{2}{*}{\multicolumn{2}{|c|}{ Model }} & $\begin{array}{c}\text { Standardized } \\
\text { Coefficients }\end{array}$ & & \multirow[b]{2}{*}{ Sig. } \\
\hline & & Beta & $t$ & \\
\hline \multirow[t]{3}{*}{1} & (Constant) & & 2.146 & .035 \\
\hline & $x 1$ & .493 & 6.277 & .000 \\
\hline & $x 2$ & .380 & 4.835 & .000 \\
\hline
\end{tabular}

Sumber : Olah data utama yang diperoleh tahun 2019

\section{Hasil Uji Regresi}

Berdasarkan tabel persamaan regresi diatas dapat disusun sebagai berikut :

$\mathrm{Y}=\beta 10.493+\beta 20.380+e l$

Keterangan :

Y adalah variabel Kinerja Manajerial Keuangan

$\mathrm{X} 1$ adalah variabel Teknologi Informasi

X2 adalah variabel Sistem Informasi Perpajakan

Dari persamaan (1) Koefisien regresi $\beta 1$ (beta) $=0.493$, karena hasilnya positip yang menunjukkan bahwa semakin tinggi teknologi informasi akan berpengaruh positip terhadap makin tinggginya kinerja manajerial keuangan. Berdasarkan nilai $\beta 2$ (beta)= 0.380 , karena hasilnya positip yang menunjukkan bahwa kenaikan nilai sistem informasi perpajakan akan berkorelasi positip kepada makin tinggginya performa kinerja keuangan.

\section{KESIMPULAN}

Hasil dari penelitian yang dilakukan di wilayah Kabupaten Semarang menunjukkan pertama, teknologi informasi secara signifikan berpengaruh positif terhadap kinerja manajerial keuangan. Kedua, sistem informasi perpajakan secara drastis berdampak positif terhadap kinerja manajerial keuangan. Ketiga teknologi informasi dan sistem informasi perpajakan secara simultan secara signifikan terhadap kinerja manajerial keuangan. Keterbatasan dalam penelitian kami adalah hanya menyajikan 2 variabel independennya dan pengolahan data belum menggunakan software terupdate untuk sebagai perbandingan hasil menggunakan software terbaru. Saran dan masukan kepada peneliti selanjuttnya supaya menambahkan variabel yang lebih spesifik dalam jenis teknologi informasi agar signifikansinya dapat memberikan kontribusi yang maksimal bagi kemajuan industri manufaktur khususnya. Peneliti selanjutnya supaya dapat menggunakan software analisis statistik yang terbaru dan menggunakan data kuantitatif dalam penelitian selanjutnya. 


\section{UCAPAN TERIMAKASIH}

Kami mengucapakan terima kasih terhadap seluruh pihak yang terlibat dalam pengisian kuisioner yaitu responden dan pihak institusi atau perusahaan yang bersedia memberi ijin dalam penyebaran kuisioner guna penelitian ini.

\section{DAFTAR PUSTAKA}

Adnan Hakim. (2016). Model Struktural Hubungan Teknologi Informasi, Kualitas Informasi dan Kinerja Manajerial Industri Kreatif Percetakan Digital. Jurnal MIX, Volume VII, No. 1, Februari 2016.

Anik, I., \& Rico, A. (2018). Pengaruh Karakterstik Sistem Informasi Manajemen Terhadap Kinerja Manajerial dengan Desentralisasi Sebagai Variabel Moderating. Jurnal Akuntansi dan Keuangan Vol. 9 No. 1, Maret 2018.

Ardhi, K., Yusralaini, \& Devi, S. (2015). Pengaruh Teknologi Informasi, Saling Ketergantungan, dan Strategi Bisnis Terhadap Kinerja Manajerial dengan Karakteristik Sistem Akuntansi Manajemen (SAM) Sebagai Varaiabel Intervening pada Bank Umum di Kota Pekanbaru. Jom FEKON Vol. 2, No. 1.

Ayu, N. D. P., \& Sri, S. (2016). Pengaruh Partisipasi Anggaran, Teknologi Informasi, dan Kualitas Informasi Manajemen, Terhadap Kinerja Manajerial (Studi Empiris pad Perusahaan Manufaktur di Kabupaten Pati). Serat Acitya-Jurnal Ilmiah UNTAG Semarang ISSN:2302-2752, Vol. 5 No. 1, 2016.

Frestilia. N., 2013. Pengaruh Pemanfaatan Teknologi Informasi, Karakteristik Informasi Sistem Akuntansi Manajemen Dan Ketidakpastianlingkungan Terhadap Kinerja Manajerial (Studi Empiris Pada Perusahaan Perbankan Di Kota Padang). Jurnal Akuntansi. Universitas Negeri Padang. Volume 1 No. 1.

Hansen dan Mowen. 2009. Akuntansi Manajerial. Jakarta: Salemba Empat.

Herda Nengsy. (2018). Pengaruh Sistem Informasi Akuntansi dan Penggunaan Teknologi Informasi Akuntansi Terhadap Kinerja Manajerial pada Perbankan di Tembilahan. Jurnal Akuntansi dan Keuangan Vol. 7 No. 1 Januari-Juni 2018.

Hutahaean Japerson. 2015. Konsep Sistem Informasi. Yogyakarta: Deepublish Publisher

Joko, S., \& Gun, G. (2018). Pengaruh Budaya Organisasi, Teknologi Informasi, dan Sistem Informasi Akuntansi Manajemen Terhadap Kinerja Manajerial PT. Propan Raya I.C.C Cab. Bandung. Jurnal Akuntansi, Audit dan Sistem Informasi Akuntansi (JASa), Vo. 2 , No. 4, Desember 2018.

Satria, A., Andreas, \& Enni, S. (2015). Pengaruh Sistem Informasi Akuntansi Manajemen dan Teknologi Informasi Terhadap Kinerja Manajerial. Jom FEKON Vol. 2, No. 2 Oktober 2015. 